Sweden were considered to be timber exporting countries, while Denmark, Germany and Switzorland were classified as timber producing and timber importing countries. Britain was considered to be the sole timber importer.

The report shows that the share of forestry in the gross national product between 1953 and 1962 wass highest for Sweden and Finland, but that a declining trend is evident everywhere. Despite this, net production value of forestry in absolute figures has remained approximately constant. In some cases, declining timber prices have been compensated by increased timber output. Germany is the largest consumer of forest products and in 1960 use of forest products in Britain amounted to only half the consumption in Germany. Wood consumption per head has increased in Sweden, Austria, Germany and Switzerland and decreased for Finland and Norway.

One of the most important purposes of the study was to compare the prices of roundwood in the different countries, because these prices determine the revenue which the forest owners receive from timber sales: the distance which the saw logs have to be transported to the consuming centres seems to have a decisive influence. Prices for saw logs are highest in Switzerland and the highest prices for pulpwood are also paid in Switzerland.

Administrative or overhead costs in forestry are highest in Germany and lowest in Norwegian crown forests. And the report suggests that a systematic levelling of the standard of living of the workers is taking place. Finally, the report concludes that Switzerland makes the biggest profits from forestry.

\section{MRC Appointment}

SIR Harold Himsworth, who has been sccretary of the Medical Research Council since 1949, is to retire at the end of Septembcr or earlier. His successor will be Dr J. A. B. Gray. When Dr Gray, previously professor of physiology at University College, London, was appointed second secretary of the council in May 1966 , it was widely understood that he would succeed Sir Harold.

Sir Harold Himsworth became secretary at the age of 44. After a distinguished academic career, also at University College, he was appointed professor of medicine at London University and director of the University College Medical Unit. He was knighted in 1952 and elected to the Royal Society in 1955. Under his aegis the budget of the MRC has grown from $\mathfrak{E 1 . 6}$ million in 1949 to $\mathfrak{f 1 4 . 2}$ million in 1967-68. During the same period, the number of staff has increased from 1,401 to 3,529 .

\section{Parliament in Britain}

Nuclear Stations

The Minister of Technology, Mr A. Wedgwood Benn, put the total expenditure on the development of the Magnox system for civil use at about $£ 20$ million, just over half relating to the development of fuel elements, in respect of which appropriate surcharges were included in fuel prices. If charges were imposed, sufficient when discounted to 1967 to cover the remaining cost of development of the reactor system itself, the average cost of generation from Magnox stations would rise by about $0 \cdot 007 \mathrm{~d}$. per unit, assuming 20 years' life and 75 per cont load factors. The expenditure to March 31, 1967, on the development of the Advanced Gas-Cooled Reactor system amounted to 289 million. Whether a royalty of $0.014 \mathrm{~d}$. per unit would recover these costs in full depended on how many such stations were built and how much electricity they generated. (Written answers, December $I 1$ and 12.)

\section{Students}

Mrs S. Wrutrams, Minister of State, Department of Education and Science, estimated that the annual cost to public funds of a student who completed his course at a college of education was about 2785 , and that the estimated annual cost to the Exchequer was about $£ 510$. Non-graduate entrants to courses of initial teacher training numbered 29,058 in 1965 and 33,378 in 1966; the provisional figure for 1967 was 36,500. Most of these students are following 3 year courses; of the students who entered in 1961, 1962 and 1963, about 90 per cent completed their courses satisfactorily. About 4 per cent of entrants did not continue in training beyond the first year of the course. For 1966-67 the technical colleges admitted to advanced courses some 27,000 full time and sandwich students, 36,000 part-time day and 28,000 "evenings only" students. It is estimated that in the academic year 1971-72 total recurrent expenditure by universitics (other than expenditure on research contracts and other self-balancing items and local authority rates) will be about $£ 200$ million with student numbers between 220,000 and 225,000 , giving an average expenditure per full-time student of about $£ 925$, compared with $£ 835$ in the academic year 1966-67. The fourth annual report of the Universities Central Council on Admissions gives a total of 13,535 admissions by universities in Great Britain to first degree and first diploma courses in purc science starting in October 1966, and estimates that places could have been found for about another 1,000 if more suitably qualified candidates had come forward. (Written answer, December 14.)

\section{Oceanography}

Is an adjournment debate in the House of Commons on December 11, Mr T. Dalyell raised questions about the development of the marine sciences and environment and the general state of British oceanography. Replying for the Government, the joint Parliamentary Secretary, Minister of Technology, Dr J. Bray, concentrated on the technological rather than the scientific aspects. The integration of the Ministry of Aviation with the Ministry of Technology had facilitated the combination of those parts of the defence research problem and the eivil research programme which fall in this field. Following the Harwell Conference a working party had been asked first to review research and development in progress on all aspects of marine science and technology in the United Kingdom, and secondly, to identify areas of marine science and technology which are likely to be the most profitable economically and to consider what further research and development would be necessary to exploit them. Thirdly, the working party was asked to advise on a programme of action and on means of co-ordinating the existing and proposed programmes of research and devclopment. 